\title{
Evaluation of sediment transport empirical equations: case study of the Euphrates River West Iraq
}

\author{
Sadeq Oleiwi Sulaiman ${ }^{1} \cdot$ Nadhir Al-Ansari $^{2}$ (i) $\cdot$ Ahmed Shahadha $^{1} \cdot$ Rasha Ismaeel $^{1} \cdot$ Sura Mohammad $^{1}$
}

Received: 7 December 2020 / Accepted: 23 April 2021 / Published online: 5 May 2021

(C) The Author(s) 2021

\begin{abstract}
Sediment transport in rivers is an important and complex process. It is very important to know the nature and quantities of sediments transported in course of rivers to achieve prudent water management. Due to the presence of most of the important projects on or near the banks of the river in the study area, so there is always a fear that these projects will be affected by the processes of erosion, transport, and sedimentation among the decision makers. Therefore, there is a need to develop our knowledge of the suitable equations that can be applied with acceptable accuracy to obtain satisfactory results for monitoring the processes of erosion, sedimentation, and transport that occur in River path to monitor and anticipate the changes taking place in the areas of the riverbanks. This study was carried out to check the reliability of different sediment transport formulas using data collected from the Euphrates River at the thermal power station in Al Anbar province, Iraq. The study also aimed to select the best formula for this site. Hydrological data have been collected. These were used for computing the total sediment load in the river at a specified cross-section using common sediment transport formulas ascribed to Ackers-White, Bagnold, Yang, Colby, Shen and Hung, and Engelund-Hansen. The performance of these formulas was assessed based on the accuracy of the predictions of the observed sediment load within a limited discrepancy ratio. The evaluations showed that the Engelund-Hansen formula represented the best formula for this river reach.
\end{abstract}

Keywords Sediment transport $\cdot$ Bed load $\cdot$ Suspended load $\cdot$ Euphrates River $\cdot$ Sediment transport formulas

\section{Introduction}

Most rivers are self-formed, or alluvial (Sui-ji and Jin-ren 2002). The distinctive path is created by streams and alluvial rivers mobilizing and transporting sediment. With regard to alluvial channels, the width and depth of the channel reflect the water flow as well as the nature of the material which makes up the channel boundaries. Typically, rivers running through soft material have high sediment loads in comparison to the rivers which are exposed to bedrock, since much of

Responsible Editor: Broder J. Merkel

Nadhir Al-Ansari

nadhir.alansari@1tu.se

Sadeq Oleiwi Sulaiman

sadeq.sulaiman@uoanbar.edu.iq

1 College of Engineering, University of Anbar, Ramadi, Iraq

2 Civil, Environmental and Natural Resources Engineering, Lulea University of Technology, 97187 Lulea, Sweden sediment load is derived from the bottom and sides of the channel (Salih et al. 2020). Today, one of the major issues facing water resource managers is the impact of bed load and suspended sediment transport on the resident aquatic organisms and quality of water (Tao et al. 2019). In addition, the majority of construction activities near or in the watercourse have the potential to result in reduced stability of the adjacent riverbanks and/or increasing the bed load and suspended sediment transport, as well as turbidity. Generally, sediment transport rates are divided into bed load, suspended sediment load. The suspended sediment load is sometimes further divided to the suspended bed material load and the wash load. The wash load sediment is the fine grain-size fraction derived from the catchment surface. The key difference between the wash load and the suspended bed material and bed load is that the wash load is supply controlled whereas the latter are generally not supply controlled but controlled by the transport capacity of the river. The wash load represents very fine sediment particles transported in suspension by the flow. The transport law for wash load is, therefore, very different from that for bed load and the suspended bed material load (Khullar 
et al. 2010). The rate of transport of wash load is considered to depend upon the supply rate from the upstream catchment and this cannot be uniquely related to the hydraulic parameters of the flow. While the transport of suspended bed material in alluvial channels is typically assumed to be controlled by river hydraulics and the sediment supply within the channel bed and banks, the controls on wash load transport are likely to be more variable and complex. The wash load is supplied from upland catchment sediment sources and delivered to the drainage network by overland flow during runoff produced by precipitation. Wash load sediment is highly mobile and is not commonly deposited within the channel bed. The find of origin suspended sediment sources catchment is attended by difficulty (Collins and Walling 2004). Most of the wash load material in the Euphrates River within the study area comes from the surface runoff after the heavy rainstorms that fall on the catchments in the desert upstream of the study area. The days during which the sediment samples were taken were not preceded by any rainfall; therefore, no presence of washing load material is expected among the suspended load materials. Because the study area is in an arid area and the flow of the river is controlled by the Haditha dam which is located about $130 \mathrm{~km}$ upstream of the study reach and traps the wash load of the river, wash load was excluded from the measurement of total sediment load and ignored from calculations (Khullar et al. 2010; Mustafa et al. 2017; Walling and Collins 2016; Yuill and Gasparini 2011). Most sediment transport equations are obtained assuming that the sediment transport rate can be determined from the dominant hydraulic variables (Afan et al. 2016). Because of the lack of consistency of the assumptions involved, compatibility is often poor when such equations are applied for flow conditions different from those for which they were developed. The calculated rates of sediment transport often differ from each other and from measured (Sharafati et al. 2019). The commonly used sediment transport functions include those developed by Yang (1973), Colby (1960), Ackers and White (1973), Bagnold (1956), Shen and Hung (1972), and Engelund-Hansen (1967) (Ackers and White 1973; Engelund and Hansen 1967; Mays 2010; Mustafa et al. 2016). The transport of sediment in the Euphrates River within the Iraqi borders has been studied by many researchers who have estimated the suspended sediment and the bed load at a number of sites on the Euphrates River. The accuracy of the results reflects field data available for bed load calculation and the reliability of the suspended load measurements. Some researchers have developed relationships with the sediment transport depending upon the amount of discharge passing through the river. The annual sediment load passing through the Euphrates River within Al Anbar province for various studies was estimated to be between $1.9 * 10^{6}$ tonne/year and $2.1 * 10^{7}$ tonne/year (Al-Ansari et al. 2015, 2018; Al-ansari et al. 1988; Khassaf and Al-Rahman 2005; Sulaiman et al. 2019b).
The process of erosion and sedimentation that occurs continuously during the process of water flow along the Euphrates River in the study area is a subject of great concern, especially after each release of high discharges from Haditha Dam upstream of the study area. There are many industrial and commercial establishments built on or near the banks of the river that will be affected in one way or another by the erosion, sedimentation, and transportation processes that take place in the river. Therefore, with the increase in the number of projects on the banks of the river in the study area, which is closely affected by the geomorphological dynamics of the river basin, there is a need to develop our knowledge of the mechanisms of sediment transport and management and the equations that can be applied with acceptable accuracy to obtain satisfactory results for monitoring the processes of erosion, sedimentation, and transport that occur in River path to monitor and anticipate the changes taking place in the areas of the river banks and the associated transport of pollutants and fertile along these banks. To the best knowledge of the current research, in this study, sediment transport was calculated by applying several well-established empirical equations to the Euphrates River. Moreover, many researchers use sometimes numerical methods to simulate the flow of water and sediment transport. Generally, the finite element (FE) approach proved to be a robust approach that has been used by many researchers to evaluate not only sediment transportation but other geotechnical applications as well (Alimohammadi et al. 2021a, b; Ferrarin et al. 2008); however, this approach is out of the scope of this research. The goal of this study was to provide decision makers and hydraulic engineers with an accurate and reliable sediment transport equation that can be applied for designing the river morphological aspects and river engineering management.

\section{Study site}

The study reach for this research is the part of the Euphrates River opposite Al Anbar thermal power plant, which is located in the west of Iraq in Al Anbar province, northwest of the city of Ramadi at longitude $\left(43^{\circ} 01^{\prime} 17^{\prime \prime}\right)$ and latitude $\left(33^{\circ} 32^{\prime}\right.$ $\left.11^{\prime \prime}\right)$. This area is considered to be one of the important areas of the sedimentary plain through which the Euphrates River passes, Fig. 1 (Al-Mimar et al. 2018; Najm et al. 2020). The location was developed as a type of thermal power plant, where the station works by burning fuel such as heavy oil, creating high-temperatures, and high-pressure steam; such steam was applied to drive a steam turbine, which drives the power generator. The thermal power plant withdraws water from the Euphrates River through the intake upstream of the plant at a flow rate of up to $90 \mathrm{~m}^{3} / \mathrm{s}$ when operating the plant at full capacity. This water is used to cool the turbines and is returned to the river after allowing its temperature to reduce to 


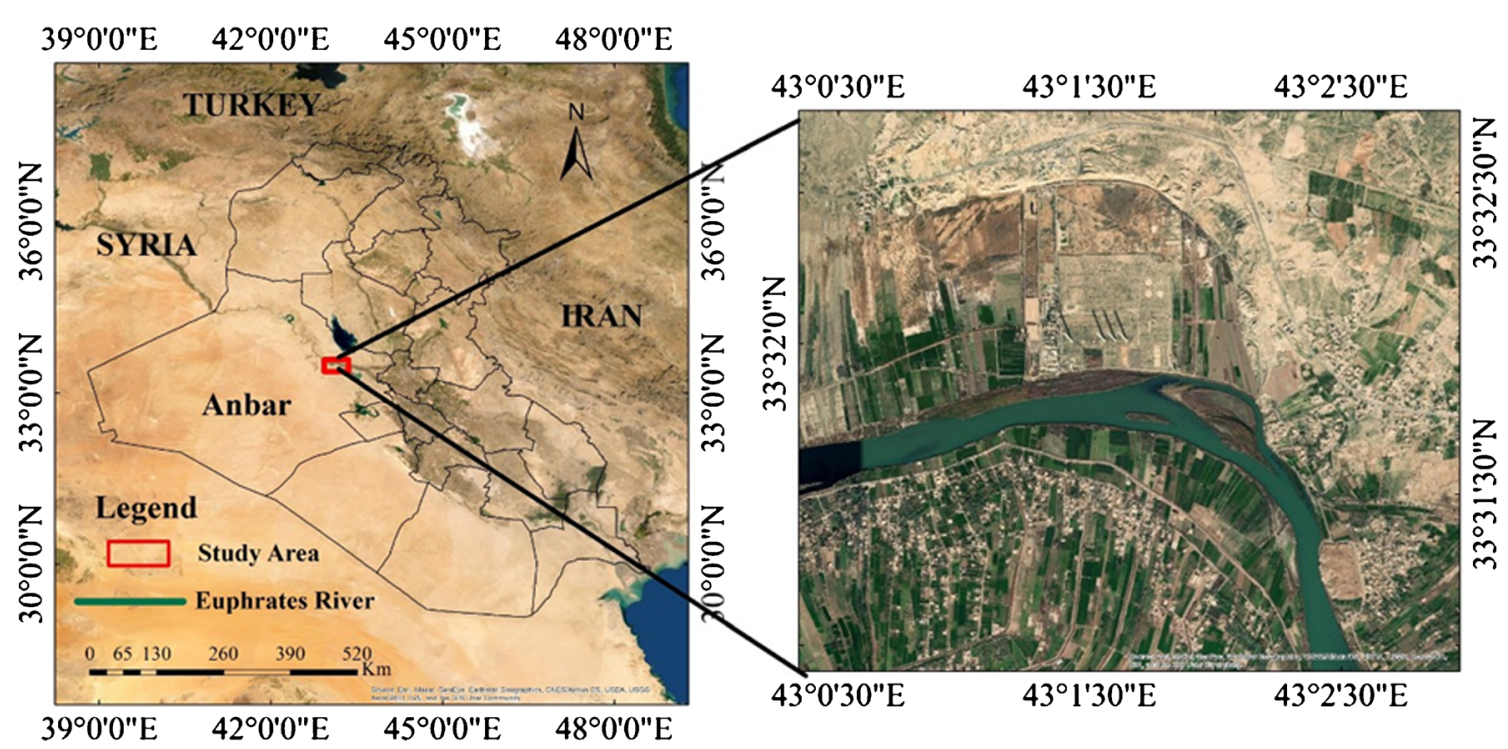

Fig. 1 The location of the study reach located on the Euphrates River in Anbar Province

the permitted limits. The sedimentation and sand islands in front of Al Anbar thermal power plant intake became a problem and thus emerged an urgent need to estimate the amounts of sediments transferred through this section of the river and develop solutions for the problems (Al-Ansari et al. 2019; Reisenbüchler et al. 2020; Sulaiman et al. 2019a).

\section{Materials and Methods}

\section{Data collections}

The data collected for this study included the bed load, the suspended load, bed material particle size, flow velocity, water temperature, and width and bed elevation for the Euphrates River at the Al Anbar thermal power plant. Data collection extended from Jun. 2019 to Sep. 2019. Monthly samples were collected from five verticals in the cross-section for 4 months. In the fourth month, only four verticals were used to measure the bed load and the suspended load due to the shallowness of the fifth measurement point and the inability to access the measuring point with the boat used for the measurement program. As a result, only four points were used to represent the entire width of the river for this measurement. The discharge of the Euphrates River in the study reach is controlled by the Haditha Dam. Therefore, the discharges in this reach do not vary greatly during most days of the year, and the presence of high discharge through the river is an exceptional event that occurs only once every several years. So, the flows in which the measurements took place were considered to be representative of the normal flow of the river during the year. The river survey was carried out using a boat equipped with anchors to position it at the desired location. The boat is directed to the location of the sampling points by a surveyor on the bank by a laser using a total station device. After the boat reaches the required measurement point, the boat is fixed by the anchor, then the depth of the water is measured using the echosounder device installed on the boat, and the temperature of the water is measured. After that, the samples of the bed load, suspended load, and bed material load were collected. The total river width (W) was divided into five vertical widths (Wi), and the location of the measurement point is in the middle distance between each of the five-measurement points, as shown in the Fig. 2a.

A BLS30 Bedload sampler (Fig. 2b) is used for measuring bed load transport in this study. It has been designed to sample the sand, silt, gravel, or rock debris which are transported by the river on or immediately above its bed. The orifice dimensions of the bed load sampler were $(76 \mathrm{~mm} * 76 \mathrm{~mm})$. The samples were collected in a polyester monofilament bag with $0.2 \mathrm{~mm}$ mesh under American Society for Testing and Materials A.S.T.M. specifications for uniformity, resistance abrasion, and wear. This does not absorb water. The bed load for each vertical of the river cross-section is estimated by multiplying the measured bed load in the BLS30 Bedload sampler by the width of the river vertical (Wi in $\mathrm{mm}$ ) divided by $76 \mathrm{~mm}$. The width of the river vertical (Wi) is varying according to the river level on the day of the measurement. The obtained bed load within $30 \mathrm{~min}$ for the relevant vertical of the river cross section is shown in the third column of Table 1. Suspended load sediment transport was measured using a depth-integrating suspended-sediment sampler (Fig. 2c) (Diplas et al. 2008). It is designed to fill at a rate proportional to the velocity of the approaching flow. By traversing the stream at a uniform speed, the sampler is moved through each vertical to receive a sample proportional to stream velocity. One sample per vertical is taken by lowering and raising the sampler to and from the stream bed to achieve a 
Fig. 2 a Euphrates River cross section; b Bedload sampler BLS30; $\mathbf{c}$ depth-integrating suspended sediment sampler; d Van Veen Grab; e VVG in the study area; $\mathbf{f}$ BLS30 in the study area

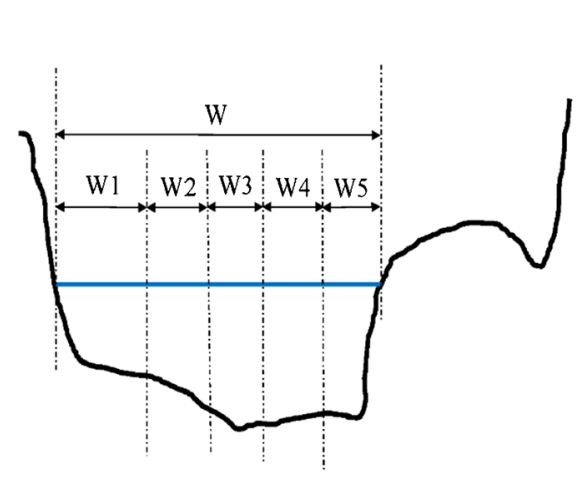

a

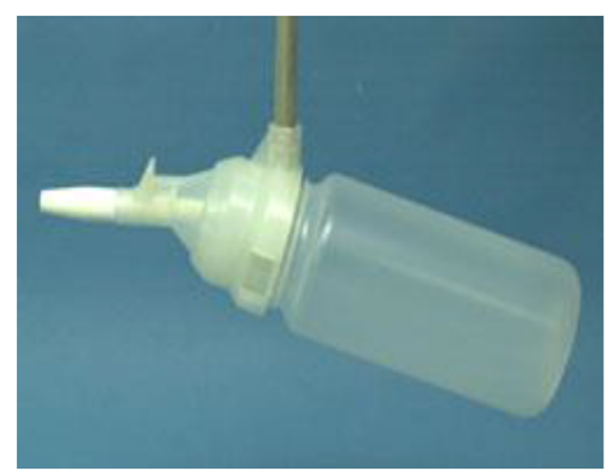

C

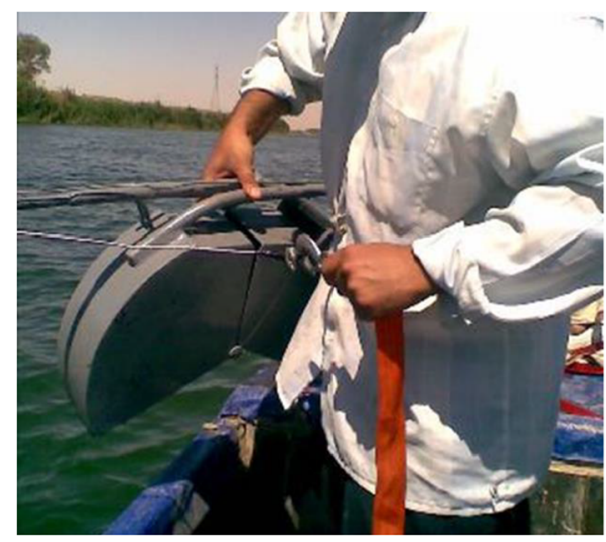

e

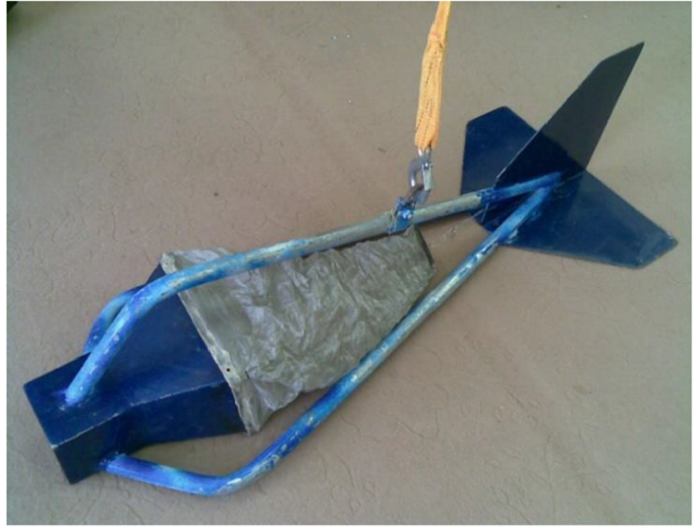

b

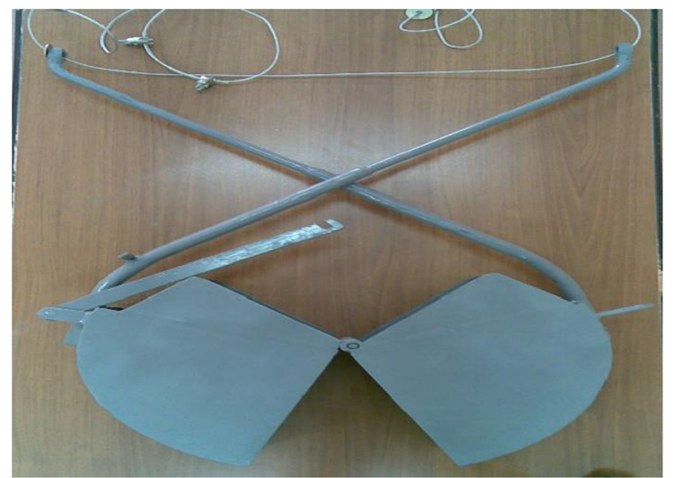

d

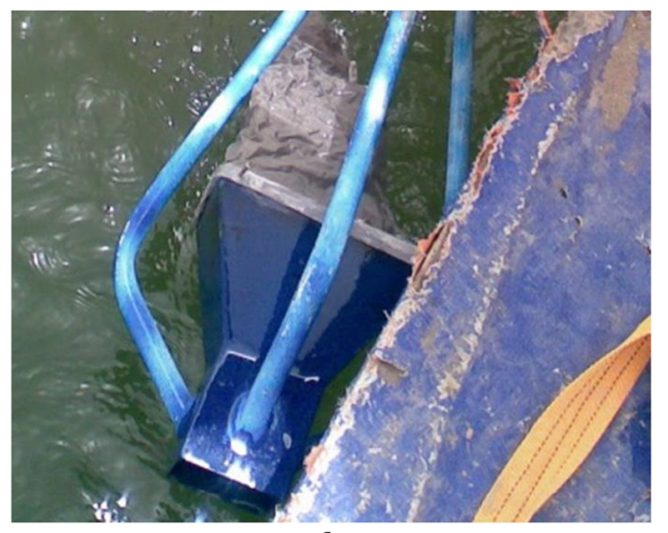

f representation of the mean concentration and particle size in each vertical. The suspended load is equal to the suspended sediment concentration of the concerned vertical multiplied by the discharge of this vertical.

A Van Veen Grab (VVG) was used for collecting bed material for examination (Fig. 2d). It can be defined as a sampler that is designed to collect the semi-disturbed samples from the riverbed. Throughout the descent, the 2 buckets will be held in an open position via a hook. When the VVG hits the bottom, the tension on the hook will be released, and the hook will be disengaged. When the sampler is raised, the buckets will close and automatically collect the sample from the bed. Figure 2 e and f illustrate the BLS30 Bedload sampler and Van Veen Grab (VVG) during the measurement process. The sediment properties and concentration for all samples are determined in the laboratory. The longitudinal slope of the Euphrates River in the study area was measured as 0.00012 . The data that have been measured are summarized in Table 1. There is a direct relationship between the flow velocity and the bed load, but it is also not to hide the stochastic behavior of sediment transport phenomena (Lisle et al. 1998), where a turbulent wave that may occur at the front of the measurement point may cause the sediment to move as a suspended load for some time and then moved as a 
Table 1 Summary of data collected

\begin{tabular}{|c|c|c|c|c|c|c|c|c|c|}
\hline Month & Vertical & $\begin{array}{l}\text { Bed load } g / 30 \\
\text { min }\end{array}$ & $\begin{array}{l}\text { Suspended load } \\
\text { concentration } \mathrm{g} / \mathrm{L}\end{array}$ & $\begin{array}{l}\mathrm{D} 65 \\
(\mathrm{~mm})\end{array}$ & $\begin{array}{l}\mathrm{D} 90 \\
(\mathrm{~mm})\end{array}$ & $\begin{array}{l}\text { Average velocity } \\
(\mathrm{m} / \mathrm{s})\end{array}$ & $\begin{array}{l}\text { Depth } \\
\text { (m) }\end{array}$ & $\begin{array}{l}\text { Width } \\
\text { (m) }\end{array}$ & $\begin{array}{l}\text { Water Temperature } \\
\left({ }^{\circ} \mathrm{C}\right)\end{array}$ \\
\hline \multirow[t]{5}{*}{ Jun. 2019} & A & 67.117 & 0.159 & 0.26 & 0.4 & 0.538 & 3.96 & 37.5 & 28.7 \\
\hline & B & 21 & 0.173 & 0.26 & 0.35 & 0.471 & 4.16 & 35.4 & 28.8 \\
\hline & $\mathrm{C}$ & 150.06 & 0.207 & 0.25 & 0.3 & 0.737 & 4.46 & 36.6 & 28.8 \\
\hline & $\mathrm{D}$ & 272.33 & 0.351 & 0.24 & 0.35 & 1.011 & 2.96 & 36.2 & 28.7 \\
\hline & $\mathrm{E}$ & 27.044 & 0.201 & 0.3 & 0.4 & 0.791 & 2.66 & 57.3 & 28.7 \\
\hline \multirow[t]{5}{*}{ Jul. 2019} & A & 2.89 & 0.294 & 0.25 & 0.3 & 0.563 & 3.79 & 36.6 & 29.6 \\
\hline & $\mathrm{B}$ & 10.29 & 0.027 & 0.25 & 0.3 & 0.55 & 3.99 & 35.4 & 29.4 \\
\hline & $\mathrm{C}$ & 17.62 & 0.344 & 0.25 & 0.3 & 0.63 & 4.29 & 36.6 & 29.4 \\
\hline & $\mathrm{D}$ & 7.91 & 0.094 & 0.26 & 0.34 & 0.611 & 2.79 & 36.2 & 29.4 \\
\hline & $\mathrm{E}$ & 23.81 & 0.196 & 0.29 & 0.4 & 0.46 & 2.49 & 56.5 & 29.7 \\
\hline \multirow[t]{5}{*}{ Aug. 2019} & A & 1.28 & 0.337 & 0.24 & 0.285 & 0.66 & 3.89 & 36.8 & 26.4 \\
\hline & $\mathrm{B}$ & 122.34 & 0.3418 & 0.25 & 0.3 & 0.671 & 4.09 & 35.4 & 26.4 \\
\hline & $\mathrm{C}$ & 257.09 & 0.043 & 0.27 & 0.35 & 0.88 & 4.39 & 36.6 & 26.3 \\
\hline & $\mathrm{D}$ & 848.36 & 0.206 & 0.29 & 0.4 & 0.912 & 2.89 & 36.2 & 26.4 \\
\hline & $\mathrm{E}$ & 348.51 & 0.22 & 0.33 & 0.39 & 0.693 & 2.59 & 56.7 & 26.4 \\
\hline \multirow[t]{4}{*}{ Sep. 2019} & A & 123.6 & 0.34 & 0.25 & 0.29 & 0.46 & 3.48 & 35.8 & 25.3 \\
\hline & $\mathrm{B}$ & 268.33 & 0.081 & 0.25 & 0.3 & 0.89 & 3.68 & 35.4 & 24.9 \\
\hline & $\mathrm{C}$ & 227.3 & 0.237 & 0.26 & 0.35 & 0.715 & 3.98 & 36.6 & 24.95 \\
\hline & $\mathrm{D}$ & 88.34 & 0.221 & 0.295 & 0.4 & 0.682 & 2.48 & 36.2 & 24.95 \\
\hline
\end{tabular}

bed load before settling as a sediment at the end time. This may be a possible explanation for some unexpected results in some of the measurements.

Using the various sediment transport functions referred to above, the total sediment load has been calculated for the individual data sets for the river using each formula and then compared with the measured values. The discrepancy ratio (r) which is defined as the ratio of computed total sediment load to the measured total sediment load for collected data was considered for comparison of performance (Haddadchi et al. 2013; Hossain and Rahman 1998).

$r=\frac{\boldsymbol{q}_{\boldsymbol{t}}, \text { computed }}{\boldsymbol{q}_{\boldsymbol{t}}, \text { measured }}$

In which $\left(\boldsymbol{q}_{\boldsymbol{t}}\right.$, computed $)$ is defined as the computed total sediment load, and ( $\boldsymbol{q}_{\boldsymbol{t}}$, measured $)$ is the measured total sediment load.

\section{Sediment transport equations}

The total load of rivers is composed to suspended and bed loads. In addition, there is a third type of load that is usually included within suspended load and is referred to as "wash load." The particles of this type are very small and lightweight which lead to a rough correlation between wash load and flow discharge (Bettes 2008). Several variables, including temperature, pressure, water discharge, particle size, and flow velocity, control the transport of sediments by the rivers. It is very difficult to deal with all these variables together. There are number of equations that deal with total load transport in rivers. Some of the equations used to compare the calculated load relative to field-measured loads are listed below (Gorczyca et al. 2020; Yang 1996):

Bagnold's equation (1956)

$q_{\mathrm{t}}=\frac{\gamma}{\gamma_{\mathrm{s}}-\gamma} \tau V\left(\frac{e_{\mathrm{b}}}{\tan \alpha}+0.01 \frac{V}{w}\right)$

$Q_{\mathrm{t}}=W q_{\mathrm{t}}$

In which $q_{\mathrm{t}}$ represents the total sediment discharge for each unit width, $Q_{\mathrm{t}}$ represents the total sediment discharge, $\gamma s$ and $\gamma$ represent the specific weights that are related to sediment and water, respectively, $\tan \alpha$ represents the ratio of tangential to normal shear force, $e_{\mathrm{b}}$ represents the efficiency coefficient, $\tau$ represents the shear force acting along the bed, $\mathrm{V}$ represents the average flow velocity, $w$ represents the fall velocity, and $W$ represents the width of the river.

Yang's equation (1973)

$$
\begin{aligned}
\log C= & 5.435-0.286 \log \frac{w d_{50}}{v}-0.457 \log \frac{u_{*}}{w}+ \\
& {\left[1.799-0.409 \log \frac{w d_{50}}{v}-0.314 \log \frac{u *}{w}\right] \log \left[\frac{V S}{w}-\frac{V_{c r} S}{w}\right] }
\end{aligned}
$$


Table 2 Comparison between the measured and computed total sediment load (tonne/day) for the different formulas

\begin{tabular}{|c|c|c|c|c|c|c|c|c|}
\hline Month & Vertical & $\begin{array}{l}\text { Measured } \\
\text { tonne /day }\end{array}$ & $\begin{array}{l}\text { Ackers and White } \\
\text { tonne /day }\end{array}$ & $\begin{array}{l}\text { Engelund and Hansen } \\
\text { tonne /day }\end{array}$ & $\begin{array}{l}\text { Shen and Hung } \\
\text { tonne /day }\end{array}$ & $\begin{array}{l}\text { Bagnold } \\
\text { tonne /day }\end{array}$ & $\begin{array}{l}\text { Yang tonne } \\
\text { /day }\end{array}$ & $\begin{array}{l}\text { Colby tonne } \\
\text { /day }\end{array}$ \\
\hline \multirow[t]{5}{*}{ Jun. 2019} & A & 1099 & 264.50 & 1250 & 52.06 & 308.7 & 225.5 & 5116.7 \\
\hline & B & 1037 & 161.87 & 974.4 & 25.90 & 255.5 & 161.41 & 6105.5 \\
\hline & $\mathrm{C}$ & 2155 & 893.69 & 2847 & 270.5 & 537.4 & 554.2 & 10358 \\
\hline & $\mathrm{D}$ & 3291 & 2057.1 & 2985 & 721.7 & 577.9 & 729.1 & 2807.1 \\
\hline & $\mathrm{E}$ & 2094 & 945.31 & 1971 & 290.1 & 517.2 & 546.2 & 1063.6 \\
\hline \multirow[t]{5}{*}{ Jul. 2019} & A & 1983 & 316.29 & 1301 & 63.48 & 310.5 & 240.1 & 4235.6 \\
\hline & B & 181.5 & 293.31 & 1298 & 57.60 & 306.2 & 236.0 & 5514 \\
\hline & $\mathrm{C}$ & 2940 & 511.31 & 1963 & 124.5 & 411.8 & 373.3 & 8388 \\
\hline & $\mathrm{D}$ & 501.4 & 307.84 & 921.0 & 66.19 & 250.0 & 201.7 & 251.1 \\
\hline & $\mathrm{E}$ & 1096 & 130.50 & 615.9 & 18.90 & 228.6 & 127.7 & 32.5 \\
\hline \multirow[t]{5}{*}{ Aug. 2019} & A & 2751 & 609.01 & 1948 & 151.7 & 411.5 & 352.6 & 6081 \\
\hline & B & 2871 & 592.26 & 2005 & 158.1 & 418.6 & 372.3 & 6960 \\
\hline & $\mathrm{C}$ & 531.2 & 1378.1 & 3671 & 550.3 & 669.5 & 804.5 & 9063 \\
\hline & $\mathrm{D}$ & 1717 & 1068.2 & 1939 & 390.2 & 445.5 & 523.4 & 1671.3 \\
\hline & $\mathrm{E}$ & 1946.9 & 512.50 & 1307.7 & 139.26 & 401.52 & 363.3 & 482.3 \\
\hline \multirow[t]{4}{*}{ Sep. 2019} & A & 1686.3 & 141.26 & 747.9 & 20.89 & 213.50 & 114.0 & 2266.3 \\
\hline & B & 817.4 & 1422.36 & 3010.6 & 508.4 & 574.11 & 635.2 & 5263.8 \\
\hline & $\mathrm{C}$ & 2138.0 & 691.23 & 2172.6 & 207.0 & 456.1 & 419.2 & 5951.8 \\
\hline & $\mathrm{D}$ & 1171.1 & 347.27 & 847.6 & 89.68 & 250.4 & 204.9 & 347.5 \\
\hline
\end{tabular}

$\frac{V_{\mathrm{cr}}}{w}=\frac{2.5}{\log \frac{u * d_{50}}{v}-0.06}+0.66$ for $1.2<\frac{u * d_{50}}{v}<70$

$$
\begin{aligned}
& \frac{V_{c r}}{w}=2.05 \text { for } 70 \leq \frac{u * d_{50}}{v} \\
& q_{t}=0.001 C V D
\end{aligned}
$$

\begin{tabular}{|c|c|c|c|c|c|}
\hline Ackers and White & Engelund and Hansen & Shen and Hung & Bagnold & Yang & Colby \\
\hline 0.24 & 1.14 & 0.05 & 0.28 & 0.21 & 4.66 \\
\hline 0.16 & 0.94 & 0.02 & 0.25 & 0.16 & 5.89 \\
\hline 0.41 & 1.32 & 0.13 & 0.25 & 0.26 & 4.81 \\
\hline 0.62 & 0.91 & 0.22 & 0.18 & 0.22 & 0.85 \\
\hline 0.45 & 0.94 & 0.14 & 0.25 & 0.26 & 0.51 \\
\hline 0.16 & 0.66 & 0.03 & 0.16 & 0.12 & 2.03 \\
\hline 1.62 & 7.15 & 0.32 & 1.69 & 1.30 & 30.39 \\
\hline 0.17 & 0.67 & 0.04 & 0.14 & 0.13 & 2.85 \\
\hline 0.61 & 1.84 & 0.13 & 0.50 & 0.40 & 0.50 \\
\hline 0.12 & 0.56 & 0.02 & 0.21 & 0.12 & 0.03 \\
\hline 0.22 & 0.71 & 0.06 & 0.15 & 0.13 & 2.21 \\
\hline 0.21 & 0.70 & 0.06 & 0.15 & 0.13 & 2.42 \\
\hline 2.59 & 6.91 & 1.04 & 1.26 & 1.51 & 17.06 \\
\hline 0.62 & 1.13 & 0.23 & 0.26 & 0.30 & 0.97 \\
\hline 0.26 & 0.67 & 0.07 & 0.21 & 0.19 & 0.25 \\
\hline 0.08 & 0.46 & 0.01 & 0.13 & 0.07 & 1.34 \\
\hline 1.74 & 3.68 & 0.62 & 0.70 & 0.78 & 6.44 \\
\hline 0.32 & 1.02 & 0.10 & 0.21 & 0.20 & 2.78 \\
\hline 0.30 & 0.72 & 0.08 & 0.21 & 0.17 & 0.30 \\
\hline
\end{tabular}

Table 3 Analysis of discrepancy ratio distributions of different formulas 
Table 4 Summary of accuracies of different formulas

\begin{tabular}{lll}
\hline Formulas & The number of estimates & Accuracy \\
\hline Ackers and White (1973) & 6 & 32 \\
Bagnold (1956) & 4 & 21 \\
Yang (1973) & 3 & 16 \\
Colby (1960) & 6 & 32 \\
Shen and Hung (1972) & 2 & 11 \\
Engelund and Hansen (1967) & 16 & 84 \\
\hline
\end{tabular}

In which $C$ is defined as the concentration of bed-material discharge (ppm), $d_{50}$ is the median particle size, $v$ is the kinematic viscosity $\left(\mathrm{ft}^{2} / \mathrm{s}\right), u_{*}$ is the shear velocity (fps), $V$ is the average velocity (fps), $S$ is the energy slope ( $\mathrm{ft} / \mathrm{ft}$ ), $V \mathrm{cr}$ is the average flow velocity (fps) at incipient motion, and $D$ is the depth of water.

Shen and Hung's equation (1972)

Shen and Hung (1972) hypothesized that the matter of sediment transport is such a complicated phenomenon that no single value for Reynolds number or Froude number, or even if it links the two values together, can describe the rate of sediment transport under all conditions. Therefore, they recommended using the following regression equation that was derived from laboratory experiments to obtain the total sediment transport rate:

$$
\begin{aligned}
& \log C_{\mathrm{t}}=-107404.45938 \\
&+324214.74734 Y-326309.58909 Y^{2} \\
&+109503.87233 Y^{3} \\
& Y=\left(\frac{V S^{0.57}}{w^{0.32}}\right)^{0.007502}
\end{aligned}
$$

where $C_{\mathrm{t}}$ is concentration of bed-material discharge (ppm), $V$ is the average velocity (fps), $S$ is energy slope ( $\mathrm{ft} / \mathrm{ft}$ ), and $w$ is the average fall velocity of sediment particles.

$$
\text { Colby's equation (1964) }
$$

$q_{t}=\left[1+\left(k_{1} k_{2}-1\right) 0.01 k_{3}\right] q_{\mathrm{ti}}$

where $q_{\mathrm{ti}}$ is the uncorrected sediment discharge compute which depend on $V, D$, and $d_{50} . k 1, k 2, k 3$ are the parameters depending on $D, d_{50}, T$, and $C$.

Engelund and Hansen's equation (1967)

$q_{\mathrm{t}}=0.05 \gamma_{s} V^{2}\left[\frac{d_{50}}{g\left(\gamma_{s} / \gamma-1\right)}\right]^{\frac{1}{2}}\left[\frac{\tau}{\left(\gamma_{s}-\gamma\right) d_{50}}\right]^{\frac{3}{2}}$

where $q_{\mathrm{t}}$ is the total sediment discharge, $g$ is gravitational acceleration, and $d_{50}$ is median particle diameter.

Ackers and White's equation (1973)

$D_{\mathrm{gr}}=d_{50}\left(\frac{g\left(S_{\mathrm{g}}-1\right)}{v^{2}}\right)^{\frac{1}{3}}$

$F_{\mathrm{gr}}=\frac{u *^{n}}{\sqrt{g d_{50}\left(S_{\mathrm{g}}-1\right)}}\left(\frac{V}{\sqrt{32} \log \left(\frac{\alpha D}{d_{50}}\right)}\right)^{1-n}$

$\log C_{A}=2.86 \log D_{g r}-\left(\log D_{g r}\right)^{2}-3.53$

$G_{\mathrm{gr}}=C_{A}\left[\frac{F_{\mathrm{gr}}}{A}-1\right]^{m}$

$C=10^{6}\left[\frac{G_{\mathrm{gr}} S_{\mathrm{g}} d_{50}\left[\frac{V}{u *}\right]^{n}}{D}\right], \quad C=p p m$

where $S g$ is the specific gravity of sediment, $\alpha ; n$ is constants.
Fig. 3 Comparisons between computed and measured total sediment transport

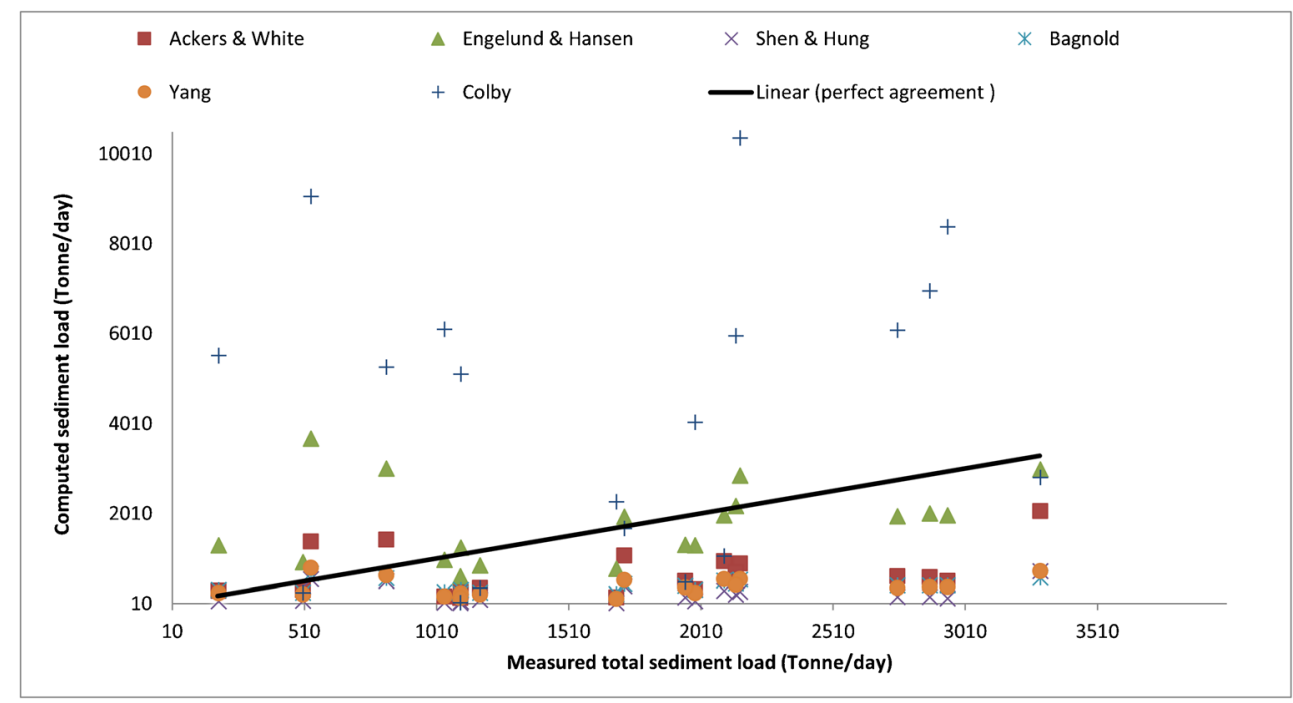




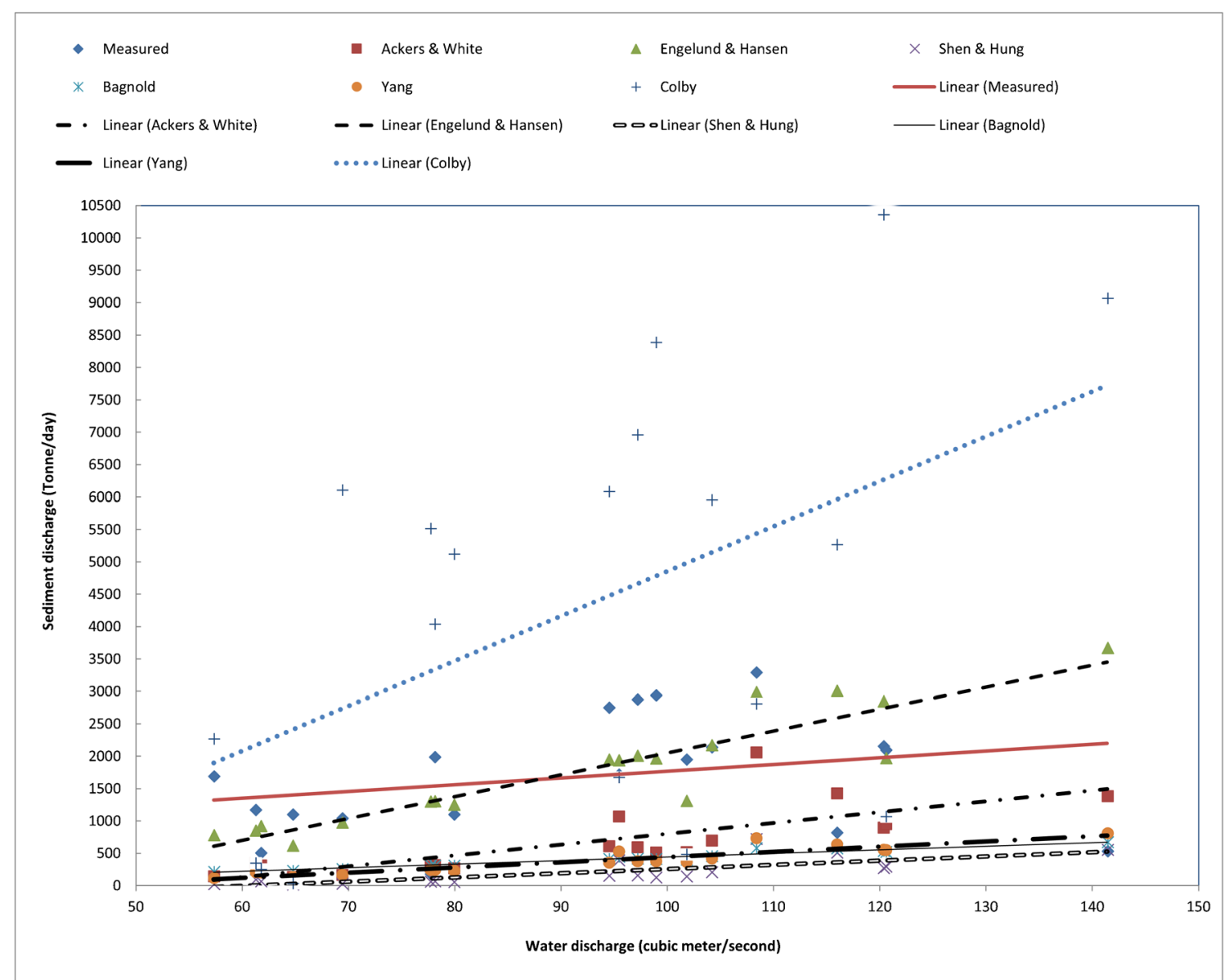

Fig. 4 Comparisons between water discharge and total sediment discharge

\section{Results and discussion}

The values of measured load and the computed total sediment load are summarized in Table 2 . These results provided by the individual formulas vary and the agreement between them is poor. This reflects the lack of generality the assumptions used in these formulas. Table 3 summarizes the discrepancy ratio for each formula. The results indicated that the mean discrepancy ratio for the Engelund and Hansen formula for 19 sets of river data was about 1.6. The number of data with discrepancy ratio between 0.5 and 2 for the Engelund and Hansen formula is 16 from 19 with an accuracy of $84 \%$ because there are only three values out of a total of 19 data values that fall outside the discrepancy ratio class between 0.5 and 2 . The accuracy of the different sediment transport functions is summarized in Table 4.

The comparisons between theses formulas indicated that the Engelund and Hansen (1967) formula provides the greatest accuracy, followed by Ackers and White (1973) and Colby (1960), and then Bagnold (1956), Yang (1973), and Shen and Hung (1972). Figure 3 shows the comparisons between measured and computed total sediment load of the
Euphrates River in the study area. Figure 3 shows that the Engelund-Hansen equation provides the closest agreement with the measured total sediment loads and this is followed by the Ackers and White equation. Figure 4 shows the relationship between the discharge of the given sector of the Euphrates River cross-section and its total sediment load discharge that is measured and computed using the various formulas. This figure also shows that the Engelund-Hansen equation is more closely in forecast with the measured total sediment load.

The data coverage for the various selected discrepancy ratios was also evaluated, and the level of discrepancy ratio was expressed as a percentage of the date coverage as shown in Fig. 5. It is evident that as the value of $r$ computed approaches one, this improves the accuracy of the values computed by the equations. Figure 5 shows that all the equations used to calculate the total sediment load for the studied area did not achieve the discrepancy ratio value very close to the unity for all the measurement values. Figure 5 shows that the Engelund and Hansen (1967) equation was the best among the equations used to calculate the total sediment load, where most of the values of the discrepancy ratio for the data were between the 
Fig. 5 Distribution of different function on the Euphrates River

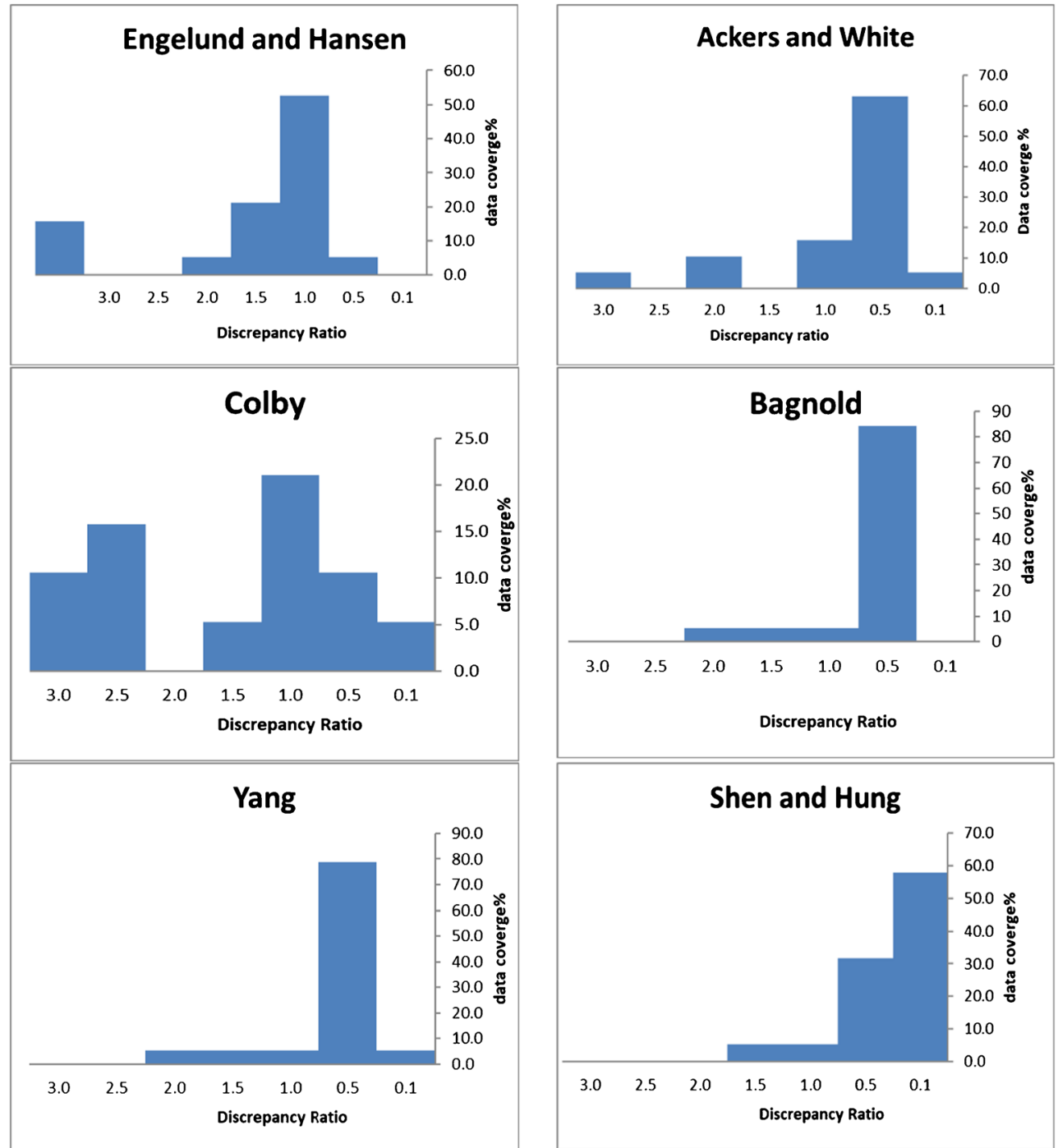

classes 0.5 and 2 and the value of the discrepancy percentage within class 1 reached $52 \%$.

\section{Conclusions}

The motivation of the current research was to investigate the capacity of some empirical equations for estimating sediment transport. This is required due to the complexity of the sediment transport process and the difficulty of conducting measurements, especially in natural rivers. It is not possible to accurately predict the total sediment load. Specification the sediment transport equations that can be applied with acceptable accuracy to obtain satisfactory results for monitoring the processes of erosion, sedimentation, and transport is very important in reducing the time and effort spent in evaluating and monitoring erosion and sedimentation processes in the study area considering the scarce and lack of measurement processes in it. Sediment transport datasets collected from an area of the Euphrates River located in Anbar Province in western Iraq were used in the current study. The findings indicated the following:

1. The Engelund and Hansen (1967) formula provided the moist reliable estimates sediment transport for this particular case study. The second order of the best formula was observed for the Ackers and White (1973) and Colby (1960) and others.

2. For the purpose of the practical engineering perspective, the Engelund and Hansen (1967) formula can be considered most appropriate for hydraulic and river engineering design and sustainability.

3. This research can be further extended in the future by applying some advanced computer models where the sediment transport can by estimated using more accurate and advanced technology. 
Acknowledgements The authors acknowledge the funding support by the Lulea University of Technology (LTU). Also, the authors would like to acknowledge their gratitude and appreciation to the data source College of Engineering, University of Anbar (UOA), Iraq

Author contribution SOS, AS, RI and SM: data curation; formal analysis; methodology; investigation; visualization; writing - original draft; review and editing draft preparation; software. NA and SOS: methodology; review and editing draft preparation. Resources; software; supervision, conceptualization; project administration; writing - review and editing.

Funding Open access funding provided by Lulea University of Technology.

Data Availability The data used in the current research has been described in the manuscript.

\section{Declarations}

Ethics approval The manuscript is conducted within the ethical manner advised by the Environmental Science and Pollution Research.

\section{Consent to participate Not applicable.}

Consent to publish The research is scientifically consented to be published.

Competing interests The authors declare that they have no competing interests.

Open Access This article is licensed under a Creative Commons Attribution 4.0 International License, which permits use, sharing, adaptation, distribution and reproduction in any medium or format, as long as you give appropriate credit to the original author(s) and the source, provide a link to the Creative Commons licence, and indicate if changes were made. The images or other third party material in this article are included in the article's Creative Commons licence, unless indicated otherwise in a credit line to the material. If material is not included in the article's Creative Commons licence and your intended use is not permitted by statutory regulation or exceeds the permitted use, you will need to obtain permission directly from the copyright holder. To view a copy of this licence, visit http://creativecommons.org/licenses/by/4.0/.

\section{References}

Ackers P, White WR (1973) Sediment transport: new approach and analysis. J Hydraul Div 99(11):2041-2060

Afan HA, El-shafie A, Mohtar WHMW, Yaseen ZM (2016) Past, present and prospect of an Artificial Intelligence (AI) based model for sediment transport prediction. J Hydrol 541:902-913. https://doi.org/ 10.1016/j.jhydrol.2016.07.048

Al-ansari NA, Asaad NM, Walling DE, Hussan SA (1988) The suspended sediment discharge of the River Euphrates at Haditha, Iraq. Geografiska Annaler. Series A, Physical Geography 70(3): 203-213 https://www.jstor.org/stable/521072

Al-Ansari N, Ali AA, Al-Suhail Q, Knutsson S (2015) Flow of River Tigris and its Effect on the Bed Sediment within Baghdad, Iraq. Open Eng 5(1):465-477. https://doi.org/10.1515/eng-20150054
Al-Ansari N, Adamo N, Sissakian VK, Knutsson S, Laue J (2018) Water resources of the Euphrates River catchment. J Earth Sci Geotech Eng 8(3):1792-9660

Al-Ansari N, Adamo N, Sissakian VK (2019) Hydrological characteristics of the Tigris and Euphrates Rivers. J Earth Sci Geotech Eng 9(4): $1-26$

Alimohammadi H, Zheng J, Buss A, Schaefer VR, Williams C, Zheng G (2021a) Finite element viscoelastic simulations of rutting behavior of hot mix and warm mix asphalt overlay on flexible pavements. Int J Pavement Res Technol 14(6):708-719. https://doi.org/10.1007/ s42947-020-0057-5

Alimohammadi H, Zheng J, Schaefer VR, Siekmeier J, Velasquez R (2021b) Evaluation of geogrid reinforcement of flexible pavement performance: A review of large-scale laboratory studies. Transportation Geotechnics 27(November 2020):100471. https:// doi.org/10.1016/j.trgeo.2020.100471

Al-Mimar HS, Awadh SM, Al-Yaseri AA, Yaseen ZM (2018) Sedimentary units-layering system and depositional model of the carbonate Mishrif reservoir in Rumaila oilfield, Southern Iraq. Model Earth Syst Environ 4:1449-1465. https://doi.org/10.1007/ s40808-018-0510-5

Bagnold RA (1956) The flow of cohesionless grains in fluids. Philos Trans A Math Phys Eng Sci 249(964):235-297

Bettes R (2008) Sediment transport \& alluvial resistance in rivers. In R\&D Technical Report W5i 609. https://publications.environmentagency.gov.uk/skeleton/publications/ViewPublication.aspx?id= 6b5ce931-4211-4143-97ad-a3bd6c70810b

Colby BR (1960) Discontinuous rating curves for Pigeon Roost and Cuffawa Creeks in Northern Mississippi: In U.S. Dept. of Agriculture, Research Service Pub. 41-46, p. 31

Collins AL, Walling DE (2004) Documenting catchment suspended sediment sources: problems, approaches and prospects. Progress in Physical Geography: Earth and Environment 28(2):159-196. https://doi.org/10.1191/0309133304pp409ra

Diplas P, Kuhnle R, Gray J, Glysson D, Edwards T (2008) Sediment transport measurements. In: Sedimentation Engineering. American Society of Civil Engineers, pp 307-353. https://doi.org/10.1061/ 9780784408148.ch05

Engelund F, Hansen E (1967) A monograph on sediment transport in alluvial streams. TEKNISKFORLAG Skelbrekgade 4 Copenhagen V, Denmark. http://resolver.tudelft.nl/uuid:81101b08-04b5-40829121-861949c336c9

Ferrarin C, Umgiesser G, Cucco A, Hsu T-W, Roland A, Amos CL (2008) Development and validation of a finite element morphological model for shallow water basins. Coast Eng 55(9):716-731. https://doi.org/10.1016/j.coastaleng.2008.02.016

Gorczyca E, Krzemień K, Jarzyna K (2020) The Evolution of Gravel-Bed Rivers during the Post-Regulation Period in the Polish Carpathians. Water 12(1):254. https://doi.org/10.3390/w12010254

Haddadchi A, Omid MH, Dehghani AA (2013) Bedload equation analysis using bed load-material grain size. Journal of Hydrology and Hydromechanics 61(3):241-249. https://doi.org/10.2478/johh2013-0031

Hossain MM, Rahman ML (1998) Sediment transport functions and their evaluation using data from large alluvial rivers of Bangladesh. In: Modelling soil erosion, sediment transport and closely related hydrological processes, pp 375-382

Khassaf SI, Al-Rahman KZA (2005) Sediment transport upstream of reservoir of Haditha Dam. Journal of Engineering and Development 9(4):45-66

Khullar NK, Kothyari UC, Ranga Raju KG (2010) Suspended wash load transport of nonuniform sediments. J Hydraul Eng 136(8):534-543. https://doi.org/10.1061/(ASCE)HY.1943-7900.0000223

Lisle IG, Rose CW, Hogarth WL, Hairsine PB, Sander GC, Parlange JY (1998) Stochastic sediment transport in soil erosion. J Hydrol 
204(1-4):217-230. https://doi.org/10.1016/S0022-1694(97) 00123-6

Mays LW (2010) Water Resources Engineering, 2nd edn. John Wiley \& Sons, Inc. https://doi.org/10.1016/S0140-6736(62)90792-4

Mustafa AS, Sulaiman SO, Hussein OM (2016) Application of SWAT model for sediment loads from valleys transmitted to Haditha Reservoir. J Eng 22(1):184-197 https://www.jcoeng.edu.iq

Mustafa AS, Sulaiman SO, Al-Alwani KM (2017) Application of HECRAS model to predict sediment transport for Euphrates River from Haditha to Heet 2016. J Eng Sci (NJES) 20(3):570-577

Najm ABA, Abdulhameed IM, Sulaiman SO (2020) Water requirements of crops under various Kc coefficient approaches by using water evaluation and planning (WEAP). International Journal of Design \& Nature and Ecodynamics 15(5):739-748. https://doi.org/10. 18280/ijdne. 150516

Reisenbüchler M, Bui MD, Skublics D, Rutschmann P (2020) Sediment management at run-of-river reservoirs using numerical modelling. In: Water (Switzerland), vol 12, Issue 1. https://doi.org/10.3390/ w12010249

Salih SQ, Sharafati A, Khosravi K, Faris H, Kisi O, Tao H, Ali M, Yaseen ZM (2020) River suspended sediment load prediction based on river discharge information: application of newly developed data mining models. Hydrol Sci J 65(4):624-637. https://doi.org/10.1080/ 02626667.2019.1703186

Sharafati A, Haghbin M, Motta D, Yaseen ZM (2019) The Application of Soft Computing Models and Empirical Formulations for Hydraulic Structure Scouring Depth Simulation: A Comprehensive Review, Assessment and Possible Future Research Direction. Archives of Computational Methods in Engineering. https://doi.org/10.1007/ s11831-019-09382-4
Shen HW, Hung CS (1972) An engineering approach to total bedmaterial load by regression analysis: Proc Sed Sym (ed) by H.W. Shen. Berkeley, CA, Water Resources Pub, chap 14

Sui-ji W, Jin-ren N (2002) Straight river: its formation and speciality. J Geogr Sci 12(1):72-80. https://doi.org/10.1007/bf02837430

Sulaiman SO, Al-Dulaimi G, Al Thamiry H (2019a) Natural rivers longitudinal dispersion coefficient simulation using hybrid soft computing model. In: Proceedings - International Conference on Developments in ESystems Engineering, DeSE, 2018-Septe(1), pp 280-283. https://doi.org/10.1109/DeSE.2018.00056

Sulaiman SO, Kamel AH, Sayl KN, Alfadhel MY (2019b) Water resources management and sustainability over the Western desert of Iraq. Environ Earth Sci 78(16):495. https://doi.org/10.1007/s12665019-8510-y

Tao H, Keshtegar B, Yaseen ZM (2019) The feasibility of integrative radial basis M5Tree predictive model for river suspended sediment load simulation. Water Resour Manag 33:4471-4490. https://doi. org/10.1007/s11269-019-02378-6

Walling DE, Collins AL (2016) Fine sediment transport and management. In: David PJW, Gilvear J, Greenwood MT, Thoms MC (eds) River Science: Research and Management for the 21st Century (First Edit, pp. 37-60). John Wiley \& Sons, Ltd. https:// doi.org/10.1002/9781118643525.ch3

Yang CT (1996) Sediment Transport: Theory and Practice. McGraw-Hill https://books.google.se/books?id=eauNAAAACAAJ

Yang CT (1973) Incipient Motion and Sediment Transport. J Hydraulics Div 99(10):1679-1704. https://doi.org/10.1061/JYCEAJ.0003766

Yuill BT, Gasparini NM (2011) Hydrologic controls on wash load sediment concentrations within a low-ordered, ephemeral watershed. J Hydrol 410(1-2):73-83. https://doi.org/10.1016/j.jhydrol. 2011.09.011 